\title{
Proteolytic hydrolysis and purification of the LRP/alfa-2-macroglobulin receptor domain from $\alpha$-macroglobulins
}

\author{
Daniel Iván Barrera ${ }^{\mathrm{a}}$, Luisa Marina Matheus ${ }^{\mathrm{b}}$, Torgny Stigbrand ${ }^{\mathrm{c}}$, \\ Luis Fernando Arbeláez ${ }^{\mathrm{a}, *}$ \\ ${ }^{a}$ Grupo de Investigación en Biomoléculas, Universidad de Pamplona, Pamplona, Colombia \\ ${ }^{\mathrm{b}}$ Unidad de Bioquímica, Facultad de Medicina, Universidad del Rosario, Bogotá, Colombia \\ ${ }^{\mathrm{c}}$ Department of Immunology, Umeå University, Umeå, Sweden \\ Received 19 October 2006, and in revised form 6 December 2006 \\ Available online 16 December 2006
}

\begin{abstract}
A new, easier and efficient purification method, using Sephacryl and DEAE-Sephacel, of the C-terminal fragment of two $\alpha$-macroglobulins, $\alpha_{2}-\mathrm{M}$ and PZP, is presented. Two larger peptides were identified for each protein as the C-terminal fragment, with molecular weights of $\sim 30 \mathrm{kDa}$ and the N-terminal sequences were determined to be SSTQDTV for $\alpha_{2}-\mathrm{M}$ and VALHLS for PZP. The smaller peptides with molecular weights of $18 \mathrm{kDa}$ correspond to a shorter C-terminal sequence of these proteins, and they were determined to be EEFPFA for $\alpha_{2}-\mathrm{M}$ and ALKVQTV for PZP, with no interfering sequences detected. The results confirmed the discriminatory capacity of the purification procedure and the purity of the fragments. This new methodology facilitates biological studies of $\alpha$-macroglobulins, and will enable elucidation of the role the $\mathrm{C}$-terminal region may exert to eliminate $\alpha$-macroglobulin-proteinases complexes from the circulation by the LRP/receptor.
\end{abstract}

(C) 2006 Elsevier Inc. All rights reserved.

Keywords: PZP; $\alpha$-Macroglobulins; C-terminal region; Chymotrypsin

Both pregnancy zone protein (PZP) ${ }^{1}$ and $\alpha_{2}$-macroglobulin $\left(\alpha_{2}-\mathrm{M}\right)$ belong to the denominated $\alpha$-macroglobulin $(\alpha-$ Ms) subgroup family, which also contains the complement subgroup comprising the complement factors $\mathrm{C} 3, \mathrm{C} 4$ and C5 [1]. PZP shares $71 \%$ aminoacid homology with $\alpha_{2}-\mathrm{M}$ and $24 \%$ with $\mathrm{C} 3$. The aminoacid sequence identity between complement factors $\mathrm{C} 3$ and $\mathrm{C} 4$ is $29 \%$ [2]. PZP, $\alpha_{2}-$ $\mathrm{M}, \mathrm{C} 3$ and $\mathrm{C} 4$, but not $\mathrm{C} 5$, contain an internal thiolester [3]. $\alpha$-Ms are synthesized as $180-200 \mathrm{kDa}$ monomers, and are held together by disulphide bonds [4]. PZP was initially

\footnotetext{
${ }^{*}$ Corresponding author. Fax: +577 5685304x156.

E-mail address: luifer@unipamplona.edu.co (L.F. Arbeláez).

1 Abbreviations used: PZP, pregnancy zone protein; $\alpha_{2}-\mathrm{M}, \alpha_{2}$-macroglobulin; DTBN, 5,5'-dithiobis-(2 nitrobenzoic acid); PTI, pancreatic trypsin inhibitor; PMSF, phenylmethylsulfonyl fluoride; MA, methylamine; DMSO, dimethylsulfoxide; HRP, horseradish peroxidase; EDTA, ethylenediaminetetraacetic acid; CT, $\alpha$-chymotrypsin; PEG, polyethylene glycol.
}

detected by starch gel electrophoresis, when sera from pregnant women were compared with sera from their newborn babies and non-pregnant women [5]. Expression of PZP is hormonally induced during pregnancy, and the levels reach as high as $1 \mathrm{mg} / \mathrm{ml}$ [6]. The increment occurs at the end of the first trimester after which the serum levels remain rather constant at a plateau level. The protein is synthesized exclusively by maternal tissues including the liver and connective tissue cells. All humans have high concentrations of $\alpha_{2}-\mathrm{M}$, and hitherto there is no reported case of its absence. During pregnancy the levels of $\alpha_{2}-\mathrm{M}$ increase approximately $20 \%$, but $\alpha_{2}-\mathrm{M}$ is not induced by estrogens $[7,8]$. The putative biological role of $\alpha_{2}-\mathrm{M}$ as a proteinase inhibitor is based on the fact that this protein can be cleaved to generate a "bait region" [9] by proteinases from all four classes of proteinases [10-14].

The interaction of plasmin and trypsin with $\alpha_{2}$-M has been studied both in vivo and in vitro, and these proteases 
were found to bind differently to $\alpha_{2}$-M depending on the concentration of the proteases. Both of these $\alpha_{2}$-M-complexes were found to be cleared from the circulation by a receptor on the cell surface, and in this process the C-terminal domain of the $\alpha$-Ms plays a pivotal role [15]. For this reason, the $\mathrm{C}$-terminal domains of $\mathrm{PZP}$ and $\alpha_{2}-\mathrm{M}$ were isolated and sequenced, and they share $85 \%$ homology. Even though the differences between these domains are small, immunological assays with monoclonal antibodies are available [16-18]. There are also major differences in other common domains, especially in the dimer contact surfaces [19]. PZP and $\alpha_{2}-\mathrm{M}$ also seem to have different functions, since PZP only inhibits kallikreins, while $\alpha_{2}$-M inhibits the major part of the enzymes involved in the coagulation and fibrinolytic pathways [20-22].

The importance of the C-terminal domain relies on the fact that this region makes direct contact with the $\mathrm{LRP} / \alpha_{2}-$ $\mathrm{M}$ receptor, which eliminates the $\alpha$-Ms-proteinase complexes from the circulation [15]. The receptor binding domain of the $\alpha$-Ms has been demonstrated to be involved in the interaction with the LRP- $\alpha_{2}-\mathrm{M}$ receptor, which internalizes multiple ligands such as $\alpha_{2}$-M- and PZP-proteinase complexes $[23,24]$ as well as complexes of the tissue plasminogen activator and urinary-type plasminogen activator with plasminogen activator inhibitor type-1 $[25,26]$. Several syndromes and pathological states are related to these proteins, i.e., multiple sclerosis, and conformational aberrations in $\alpha_{2}-\mathrm{M}$ limit the capacity of this protein to eliminate systemic proteases [27]. In the case of rheumatoid arthritis, $\alpha_{2}-\mathrm{M}$ affects the cytokine level involved in the inflammatory process $[28,29]$.

In this report a new significantly improved method for isolation of the C-terminal fragment of $\alpha_{2}-\mathrm{M}$ and PZP, modified from the methods of Arbeláez et al. [16] and Jensen et al. [19] is presented. The method can be used for the purification of the receptor binding domain.

\section{Materials and methods}

\section{Chemicals and enzymes}

All buffer substances, salts and other chemicals employed were of the highest available purity.

5,5'-Dithiobis-(2 nitrobenzoic acid) (DTBN), bovine pancreatic trypsin inhibitor (PTI), $\varepsilon$-amino caproic acid, $\alpha$ chymotrypsin (EC 3.4.21.1) (CT), phenylmethylsulfonyl fluoride (PMSF), methylamine (MA), dimethylsulfoxide (DMSO), aprotinin and $p$-nitrophenyl- $p^{\prime}$-guanidinobenzoate hydrochloride, horseradish peroxidase (HRP) were from Sigma Co. Ethylenediaminetetraacetic acid (EDTA), polyethylene glycol 6000 (PEG) and zinc chloride were purchased from Merck. DEAE-Sephacel and Sephacryl S-200 HR were supplied by Amersham Biosciences. Amido Black stain and Opti 4CN kit were purchased from Bio-Rad. The monoclonal antibodies KF-2 and KG-3 were kindly provided by Dr. Torgny Stigbrand from the Umeå University in Sweden.

\section{Active site titration}

Following the methodology proposed by Chase and Shaw [30], CT yields $0.93 \mathrm{~mol}$ active site/mol enzyme when titrated with $p$-nitrophenyl- $p^{\prime}$-guanidinobenzoate hydrochloride. The concentration was determined by absorption at $280 \mathrm{~nm}$ employing $\left(\varepsilon^{1 \%}\right)_{1 \mathrm{~cm}}=20$ and a molecular mass of $25 \mathrm{kDa}$ [30].

\section{Protein purification procedure}

PZP and $\alpha_{2}-\mathrm{M}$ were purified according to the method described by Arbeláez and Stigbrand [16], from fresh pregnancy plasma obtained at the Erasmo Meoz Hospital (Cúcuta, Colombia). The purified proteins were concentrated to $3 \mathrm{mg} / \mathrm{mL}$ using an Amicon device and pelleted (dropping protein solution into liquid nitrogen). The pellets were stored at $-81{ }^{\circ} \mathrm{C}$ until use. The thiolester activity of the proteins was $98 \%$ as determined by titration with DTNB following incubation with MA [31]. The native PZP was $98 \%$ dimeric and $2 \%$ tetrameric. The concentration of PZP and $\alpha_{2}-\mathrm{M}$ were determined by absorption at $280 \mathrm{~nm}$ employing $\left(\varepsilon^{1 \%}\right)_{1 \mathrm{~cm}}=8.2$ and a molecular mass of $360 \mathrm{kDa}$ [32] for PZP; and $\left(\varepsilon^{1 \%}\right)_{1 \mathrm{~cm}}=8.9$ [33] and a molecular mass of $720 \mathrm{kDa}$ for $\alpha_{2}-\mathrm{M}$ [34].

\section{Enzyme linked immunosorbent assay of $\alpha-M s$}

Five milligrams of the monoclonal anti PZP and anti $\alpha_{2}-$ $\mathrm{M}$ antibodies RK35 and B6, respectively, were conjugated with $10 \mathrm{mg}$ of HRP using the method described by Engvall [35]. Microtiters plates (96 well, Nunc, Denmark) were coated with antibodies $\mathrm{H} 3$ and $\mathrm{B} 7$, respectively, in $0.1 \mathrm{M}$ $\mathrm{NaHCO}_{3}$ overnight at $5{ }^{\circ} \mathrm{C}$. The plates were washed with $1 \% \mathrm{NaCl}$ and $0.05 \%$ Tween 20 . The human $\alpha$-Ms antigens were diluted to levels between 0 and $100 \mathrm{ng} / \mathrm{mL}$ of human $\alpha$-Ms. The plasma samples and purification steps were added to the plates coated with antibodies and were incubated for $2 \mathrm{~h}$ at room temperature. The plates were washed as above and the HRP conjugated antibodies RK35-HRP and B6-HRP, diluted 1:2000 were added and the plates were incubated for $2 \mathrm{~h}$ at room temperature, the plates were washed again and developed by addition of $200 \mu \mathrm{L}$ of $o$ phenylendiamine containing $\mathrm{H}_{2} \mathrm{O}_{2}$ in citrate-phosphate buffer, $\mathrm{pH} 5.0$, for $15 \mathrm{~min}$. The reaction was stopped by addition of $50 \mu \mathrm{L}$ of $3 \mathrm{M}$ sulphuric acid and the Abs at $420 \mathrm{~nm}$ was determined by a Thermomax microplate reader from GTF, Gothenburg, Sweden. The amount of $\alpha_{2}-\mathrm{M}$ and PZP found in the starting batch of plasma by ELISA, were used as the $100 \%$ protein in plasma, the amount founded in each purification step was calculated in \% from the amount found in the starting material. The purifications procedures are summarized in Tables 1 and 2.

\section{Purification of the C-terminal fragments of $P Z P$ and $\alpha_{2}-M$}

PZP (3.3 mL $(10 \mathrm{mg}))$ or $\alpha_{2}$-M were dialyzed overnight against PBS (20 mM sodium phosphate, $0.15 \mathrm{M} \mathrm{NaCl}, \mathrm{pH}$ 
Table 1

Yield of PZP/ml of plasma in the different purification steps, as determined by ELISA.

\begin{tabular}{|c|c|c|c|}
\hline Procedure step & $\begin{array}{l}\text { Amount of } \\
\text { PZP (mg) }\end{array}$ & $\begin{array}{l}\mathrm{PZP} \\
\text { recovery }(\%)\end{array}$ & $\begin{array}{l}\text { Fold } \\
\text { purification }\end{array}$ \\
\hline 1. Starting material $(200 \mathrm{~mL})$ & 220 & 100 & 1 \\
\hline 2. Lysine-Sepharose chromatography & 220 & 100 & 1 \\
\hline 3. Precipitation with PEG (first) & 202 & 92 & ND \\
\hline 4. Precipitation with PEG (second) & 170 & 77 & ND \\
\hline 5. DEAE-Sephacel chromatography (pooled samples) & 140 & 64 & 8 \\
\hline 6. Zn-Sepharose chromatography (pooled samples) & 120 & 55 & 145 \\
\hline
\end{tabular}

ND, not determined.

Table 2

Yield of $\alpha_{2}-\mathrm{M} / \mathrm{ml}$ of plasma in the different purification steps, as determined by ELISA

\begin{tabular}{|c|c|c|c|}
\hline Procedure step & Amount of $\alpha_{2}-\mathrm{M}(\mathrm{mg})$ & $\alpha_{2}-\mathrm{M}$ recovery $(\%)$ & Fold purification \\
\hline 1. Starting material $(200 \mathrm{~mL})$ & 480 & 100 & 1 \\
\hline 2. Lysine-Sepharose chromatography & 480 & 100 & 1 \\
\hline 3. Precipitation with PEG (first) & 450 & 98 & ND \\
\hline 4. Precipitation with PEG (second) & 410 & 85 & ND \\
\hline 5. DEAE-Sephacel chromatography (pooled samples) & 375 & 78 & 7 \\
\hline 6. Zn-Sepharose Chromatography (pooled samples) & 250 & 52 & 27 \\
\hline
\end{tabular}

ND, not determined.

7.4), and the volume of the dialyzate was measured and the solution was made $0.1 \mathrm{M}$ with MA and incubated for $2 \mathrm{~h}$ at room temperature. Protein solutions were applied to a Sephacryl S-200 column $(120 \times 2.5 \mathrm{~cm})$ equilibrated with $0.1 \mathrm{M}$ sodium phosphate, $\mathrm{pH}$ 8.0. Following chromatography, the protein fractions were concentrated to $5 \mathrm{ml}$. The PZP-MA and $\alpha_{2}$-M-MA solutions were incubated at $37^{\circ} \mathrm{C}$ for $5 \mathrm{~min}$ with CT in a $1: 4 \mathrm{~mol} / \mathrm{mol}$ ratio. The reaction was stopped by the addition of PMSF to a final concentration of $0.5 \mathrm{mM}$ (dissolved in DMSO). Another exclusion chromatography was performed employing a Sephacryl S-200 column $(120 \times 2.5 \mathrm{~cm})$, in this case equilibrated with $1200 \mathrm{~mL}$ of $0.1 \mathrm{M} \mathrm{NH}_{4} \mathrm{CO}_{3}, \mathrm{pH}$ 8.2. The C-terminal fragments were concentrated to $3 \mathrm{mg} / \mathrm{ml}$ using $\left(\varepsilon^{1 \%}\right)_{1 \mathrm{~cm}}=5.5$ as factor [34] and dialyzed for $24 \mathrm{~h}$ with a $10 \mathrm{mM}$ acetic acid solution. The purification procedures are summarized in Tables 3 and 4.

\section{Electrophoretic analysis}

Gel electrophoresis was performed in non-denaturing ( $5 \%$ PAGE) and denaturing ( $7.5 \%$ and $12.5 \%$ SDS-PAGE) conditions according to Laemmli [36]. Protein samples of $5 \mu \mathrm{g}$ were mixed with the sample buffer $( \pm$ SDS) [36] in a 1:1 (vol/vol) ratio. For sample buffer with SDS, the proteins were allowed to react, before electrophoresis, with SDS and $\beta$-mercaptoethanol $(10 \%)$ for $60 \mathrm{~min}$ at room temperature. Boiling of samples was avoided because the thiolesters in PZP and $\alpha_{2}-\mathrm{M}$ are sensitive to thermolysis [37]. Proteins were visualized by staining with Coomassie Brillant Blue R, and silver staining. Bio-Rad's silver stain high range molecular weight marker was employed: $200 \mathrm{kDa}$ (myosin), $116.25 \mathrm{kDa}$ ( $\beta$-galactosidase), $97.4 \mathrm{kDa}$ (phosphorylase $\mathrm{b})$, $66.2 \mathrm{kDa}$ (bovine serum albumin), $45 \mathrm{kDa}$ (ovalbumin), and Bio-Rad's prestained low range molecular weight marker:

Table 3

Yield and purity of the C-terminal peptide (from $10 \mathrm{mg}$ of PZP-MA) in different purification steps, monitored spectrophotometrically at $280 \mathrm{~nm}$

\begin{tabular}{lllll}
\hline Procedure step & Total protein $(\mathrm{mg})$ & Amount of C-terminal $(\mathrm{mg})$ & C-terminal recovery $(\%)$ & Fold purification \\
\hline 1.Starting material $(5 \mathrm{~mL})$ & 10 & 1.550 & 100 & 1 \\
2. Sephacryl S-200 chromatography & 9.638 & 1.499 & 96 & 1.037 \\
3. PZP-MA digestion $(\mathrm{CT})$ & 9.638 & 1.499 & 96 & $\mathrm{ND}$ \\
4. Sephacryl S-200 chromatography & 8.8 & 1.368 & 88 & 1.136 \\
\hline
\end{tabular}

ND, not determined.

Table 4

Yield and purity of the C-terminal peptide from $10 \mathrm{mg}$ of $\alpha_{2}$-M-MA in different purification steps, monitored spectrophotometrically at $280 \mathrm{~nm}$

\begin{tabular}{lllll}
\hline Procedure step & Total protein $(\mathrm{mg})$ & Amount of C-terminal $(\mathrm{mg})$ & C-terminal recovery $(\%)$ & Fold purification \\
\hline 1. Starting material $(5 \mathrm{~mL})$ & 10 & 1.550 & 100 & 1 \\
2. Sephacryl S-200 chromatography & 9.638 & 1.499 & 96 & 1.037 \\
3. $\alpha_{2}$-M-MA digestion $(\mathrm{CT})$ & 9.638 & 1.499 & 96 & ND \\
4. Sephacryl S-200 chromatography & 8.8 & 1.368 & 88 & 1.136 \\
\hline
\end{tabular}

ND, not determined. 
$103 \mathrm{kDa}$ (phosphorylase b), $77 \mathrm{kDa}$ (bovine serum albumin), $50 \mathrm{kDa}$ (ovalbumin), $34.3 \mathrm{kDa}$ (carbonic anhydrase), $28.8 \mathrm{kDa}$ (soybean trypsin inhibitor), $20.7 \mathrm{kDa}$ (lysozyme) was employed with Coomassie staining.

\section{Protein sequence analysis}

Sequence analysis for intact PZP and $\alpha_{2}-\mathrm{M}$ protein (Fig. 1, lanes 2 and 3) and for C-terminals (Fig. 2, lanes 2 and 4, fragments 5 and 6) were performed. Proteins in the $5 \%$ native gel, and $7.5 \%$ and $12.5 \%$ SDS gel were transferred by electroblotting to a PVDF membrane (Bio-Rad) in a solution of $25 \mathrm{mM}$ Tris with $192 \mathrm{mM}$ glycine and $20 \%$ methanol, $\mathrm{pH}$ 8.3. Samples were blotted for $3 \mathrm{~h}$. Transferred bands were visualized by incubation for $2-3$ min with a solution of $0.1 \%$ amido black dissolved in distilled water. The membranes were destained in a solution containing $55 \%$ water, $35 \%$ methanol and $10 \%$ acetic acid. The sequencing was performed at Umeå University (UmeåSweden) employing the Edman degradation methodology.

\section{Western blot analyses}

Western blot analyses of the C-terminals of human $\alpha$-Ms were performed. The bands of these domains were transferred by electroblotting to an Imobilon-P transfer membrane (Millipore) from $12.5 \%$ SDS gel by tank transfer in a solution of $25 \mathrm{mM}$ Tris with $192 \mathrm{mM}$ glycine and $20 \%$ methanol, pH 8.3. Samples were blotted overnight. After transfer, the blots were allowed to dry completely. For immunodetection the membranes were incubated for $1 \mathrm{~h}$
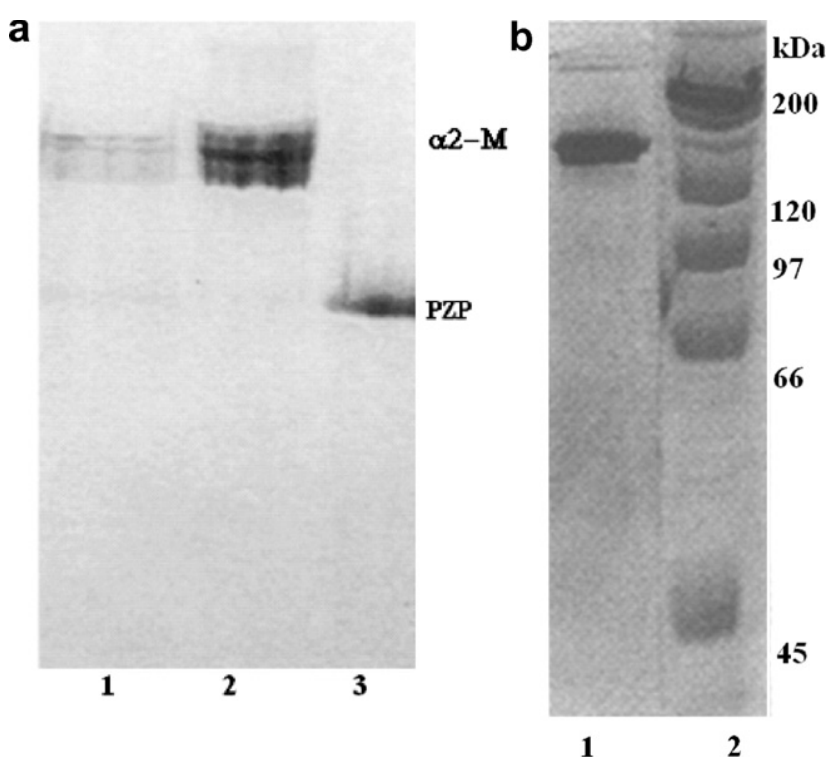

Fig. 1. (a) Electrophoresis of $\alpha-\mathrm{Ms}$ in a $5 \%$ native polyacrylamide gel, lane 1 , elution of both $\alpha_{2}$-M and PZP from DEAE-Sephacel, lane $2 \alpha_{2}$-M and lane 3 PZP eluted by $\mathrm{Zn}$-Sepharose chromatography and visualized by Coomassie staining and (b) SDS-PAGE (7.5\%) of purified PZP. The samples were visualized by silver staining; lane 1 contains $3 \mu \mathrm{g}$ of protein, lane 2 contains the molecular weight markers, as indicated in Materials and methods. with primary monoclonal antibodies reactive with $\alpha_{2}-\mathrm{M}$ and PZP C-terminals (KG-3 and KF-2, respectively) diluted 1:1000 in blocking buffer consisting of $1 \%$ BSA in PBS-T (phosphate-buffered saline: $10 \mathrm{mM}$ Na-phosphate, $\mathrm{pH} 7.2,0.9 \% \mathrm{NaCl}$ and $0.05 \%$ Tween 20). After washing the membrane three times with the same buffer, the blot was incubated with the secondary polyclonal antibody (horseradish peroxidase-conjugated anti-mouse rabbit immunoglobulin) diluted 1:2000 in blocking buffer. After three washes using PBS-T, the proteins were visualized with the Opti 4CN kit (Bio-Rad).

\section{Results}

In Fig. 1a, lane 1 the $\alpha_{2}-\mathrm{M}$ and PZP fractions obtained from the elution of DEAE-Sephacel are shown as they appear in a native polyacrylamide gel. The position of $\alpha_{2}-\mathrm{M}$ and PZP are indicated for both proteins which were completely separated without any cross contamination. A purity of approx. $98 \%$ was achieved in both cases after elution of $\alpha_{2}-\mathrm{M}$ and PZP from the Zn-Sepharose column as shown in Fig. 1b for PZP as visualized by silver staining. Tables 1 and 2 summarize the purification methods and steps as well as the fold purification for both PZP and $\alpha_{2}$ M. Furthermore, only one band of $180 \mathrm{kDa}$ was visualized using Coomassie staining of the denatured $\alpha_{2}$-M-MA and PZP-MA (Fig. 2, lanes 1 and 5), as a corroboration of the purity of these samples and the results of the sequence analyses confirmed only one sequence in each sample. The yield and purity of the peptides are presented in Tables 3 and 4 . The sequence of the N-terminal was TEPQYMV for PZP and SVSGKPQ for $\alpha_{2}-\mathrm{M}$ (Table 5). The fragment F0 (Fig. 2, upper band in lane 2) corresponds to the complex

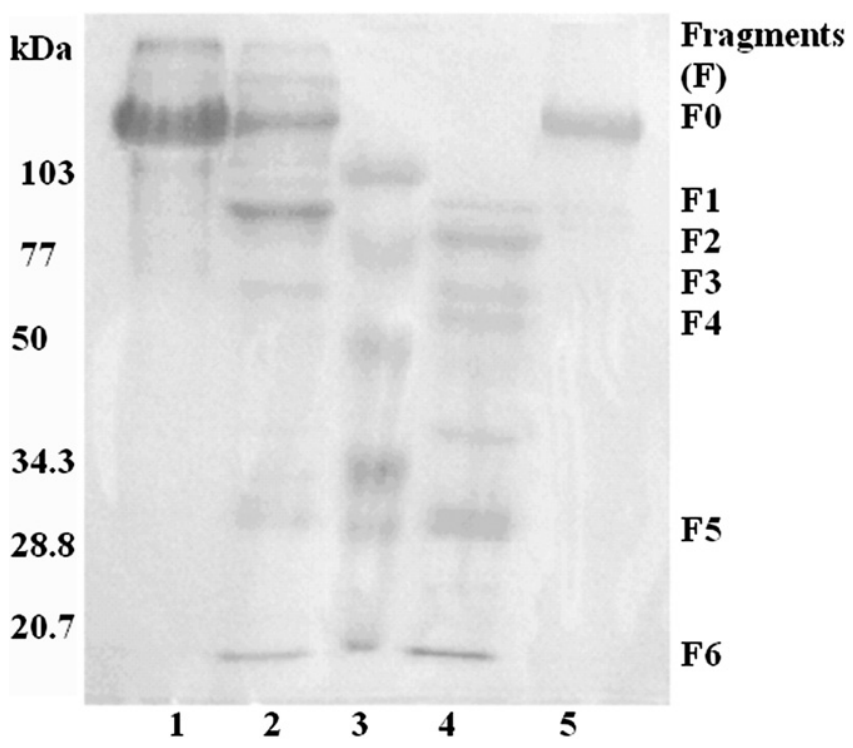

Fig. 2. SDS-PAGE (7.5\%) of digestion products of $\alpha_{2}$-M-MA and PZPMA with chymotrypsin incubated for $5 \mathrm{~min}$. at $37^{\circ} \mathrm{C}$. Lane 1 , complex $\alpha_{2}$ M-MA; lane 2, digested $\alpha_{2}$-M-MA; lane 3, molecular weight standards as indicated in Materials and methods; lane 4, digested PZP-MA; lane 5, the complex PZP-MA. 
$\alpha_{2}$-M-MA (180 kDa) undegraded by the enzyme. No high molecular weight complexes were visualized because the $\beta$ cysteinyl- $\gamma$-glutamyl thiolesters were blocked by MA. CT cleavage of the $\alpha$-Ms reveals the typical degradation fragments between 50 and $100 \mathrm{kDa}$ corresponding to the "bait region" (Fig. 2, lanes 2 and 4, fragments 1-4), and the $\sim 30 \mathrm{kDa}$ fragment is obtained from the subsequent cleavage of this domain (Fig. 2, fragment 5 and peak 2 of the exclusion chromatography, Fig. 4) identified as the C-terminal fragment $(\sim 30 \mathrm{kDa})$. The $\mathrm{N}$-terminals sequences were determined to be VALHALS for PZP and SSTQDTV for $\alpha_{2}-\mathrm{M}$, respectively. There results indicate the cleavage between the amino acids ${ }^{1260} \mathrm{Thr}-\mathrm{Val}{ }^{1261}$ in PZP (GenBank Accession No. NP_002855) and ${ }^{1248} \mathrm{Phe}_{-} \mathrm{Ser}^{1249}$ in $\alpha_{2}-\mathrm{M}$ (GenBank Accession No. NP_000005). A peptide of $18 \mathrm{kDa}$ (Fig. 2, lanes 2 and 4, fragment 6 and peak 3 in the exclusion chromatography, Fig. 3 ) in both proteins corresponds to a shorter N-terminal of these proteins, as demonstrated by sequence analysis. The $\mathrm{N}$-terminal sequences were ALKVQTV and EEFPFA for PZP and for $\alpha_{2}-\mathrm{M}$, respectively (Table 5). This indicate a cleavage between the amino acids ${ }^{1346}{ }^{P h e}-\mathrm{Ala}^{1347}$ in PZP (GenBank Accession No. NP_002855) and ${ }^{1336}$ Lys-Glu ${ }^{1337}$ in $\alpha_{2}$-M (GenBank Accession No. NP_000005). The first peak in Fig. 3 corresponds to a mixture of components with molecular weights from 50 to $180 \mathrm{kDa}$. The total yield at the $\mathrm{C}$-terminal purification procedure was approx $88 \%$. The $\sim 30 \mathrm{kDa}$ C-Terminal fragments were transferred to a hydrophobic membrane and visualized by the antibodies KG-3 for the C-terminal fragment of $\alpha_{2}-\mathrm{M}$ and KF-2 for the C-terminal fragment of PZP.

\section{Discussion}

This paper presents a new, faster and efficient purification method of the C-terminal fragments of $\alpha_{2}$-M and PZP, fragments with significance for the biological role of these proteins. Due to the homology between the C-terminal of $\alpha_{2}-\mathrm{M}$ and PZP, it is of importance to determine the amount of cross contamination of the preparations. No PZP dimers were found in the $\alpha_{2}$-M preparation; neither did $\alpha_{2}$-M tetramers appear in the PZP sample which would indicate the presence of $\alpha_{2}-\mathrm{M}$ or denaturation of PZP as judged by sequence analysis. The amount of $\alpha_{2}-\mathrm{M}$ is less than $0.1 \%$ in the PZP preparation. Both proteins were purified to approx. 98\% purity, and the determined sequences were identical to those previously reported [16].

The cleavage of the receptor binding domain of the $\alpha$-M-MA by CT demonstrated more selective degradation than cleavages with other proteases, in which several different $\mathrm{N}$-terminal sequences were found, indicating

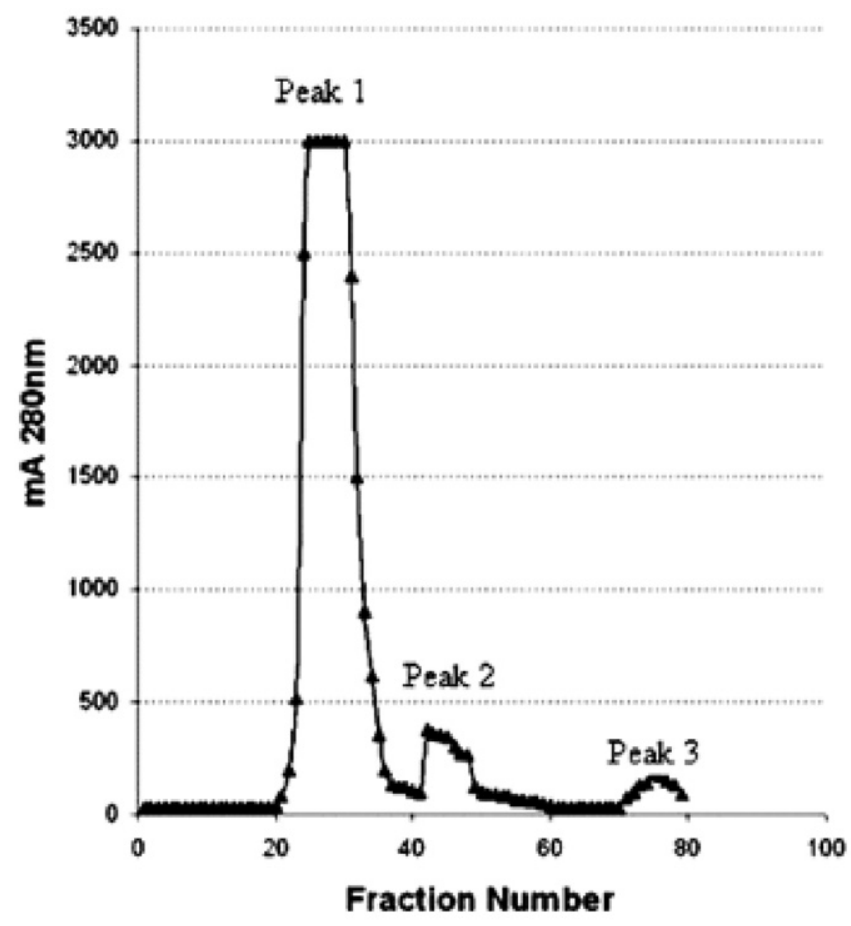

Fig. 3. Elution profile of PZP-MA digested with chymotrypsin from the Sephacryl S-200 column. Peak 1 consists of high molecular weight fragments, peak 2 is the C-terminal of PZP $(30 \mathrm{kDa})$ and peak 3 is a subsequent degradation of this domain $(18 \mathrm{kDa})$.
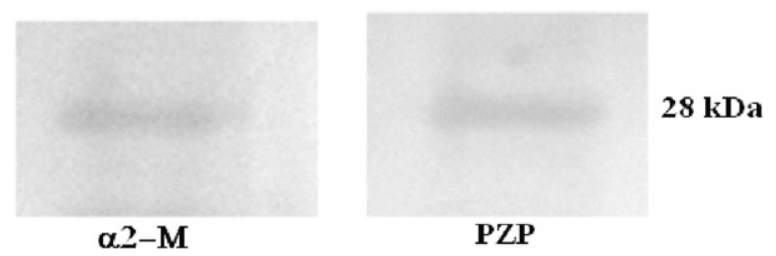

Fig. 4. The left band corresponds to the $\alpha_{2}$-M C-terminal visualized by the KG-3 monoclonal antibody and the right band is the PZP C-terminal identified by the KF-2 monoclonal antibody.

more than one cleavage site. Thomsen and Sottrup-Jensen identified different domains in $\alpha$-Ms in which they found two fragments of the C-terminal domain when hydrolyzing the $\alpha$-Ms with CT followed by PAGE-SDS electrophoresis [38]. The $\mathrm{Phe}^{1248}-\mathrm{Ser}^{1249}$ cleavage of $\alpha_{2}$-M by CT, is a typical cleavage site for this enzyme, found also in the autolysis and autolytic inactivation of CT [39]. Probably PZP is first cleaved at the same site as $\alpha_{2}-\mathrm{M}$, but is then further degraded by CT. PZP was demonstrated to be more sensitive to enzyme hydrolysis than $\alpha_{2}-\mathrm{M}$, as can be demonstrated in Fig. 2 lane 4, in which the $180 \mathrm{kDa}$ band (F0) of PZP was totally degraded, while the one for $\alpha_{2}-\mathrm{M}$

Table 5

Aminoacidic sequences of the N-terminal region and C-terminal region of $\alpha$-Ms (Fig. 3 peaks 2 and 3), determined using Edman degradation methodology

\begin{tabular}{llll}
\hline Purified protein & N-terminal sequence (180,000 Da) & Peak 2 N-terminal sequence (30,000 Da) & Peak 3 N-terminal sequence (18,000 Da) \\
\hline PZP & TEPQYMV & VALHALS & ALKVQTV \\
$\alpha_{2}-\mathrm{M}$ & SVSGKPQ & SSTQDTV & EEFPFA \\
\hline
\end{tabular}


was not (Fig. 2, lane 2 (F0)). The native and three-dimentional structure of these proteins protect them from degradation by enzymes. When $\alpha_{2}-\mathrm{M}$ and PZP were treated with MA, and expose their C-terminals, this facilitates the hydrolyzation of the C-terminal and its further degradation. CT not only cleave aromatic sites, but this enzyme has been demonstrated to cleave other sites with different catalytic constants, and the cleavage of the fragments of $\sim 30$ and $18 \mathrm{kDa}$ are in good agreement with earlier reported cleavages sites by CT [39-41]. These two C-terminal fragments present molecular weights in accordance with the sequences of the isolated fragments, which strongly suggests that these $\mathrm{C}$-terminals, are similar or the same as these previously hydrolyzed with CT but not sequenced by Thomsen and Sottrup-Jensen [38]. This new method thus allows the purification of C-terminals of $\alpha-\mathrm{Ms}$ in a selective and rapid way, avoiding the long $12 \mathrm{~h}$ incubation with papain which produces several of the low molecular weight fragments which decrease the final yield of the C-terminal fragment [16]. This new method produces only two fragments with high yield and it also requires lower amounts of $\alpha-\mathrm{Ms}$ than any other known method. The procedure is simple and allows high recuperation of the C-terminal fragment ( $88 \%$ ) which is superior to other methodologies $[16,18,34]$. The receptor binding domains of the $\alpha$-Ms were also isolated with high purity and only two C-terminal sequences for each protein were identified, both, with different size belong to the C-terminal. This confirms the selective cleavage by CT, and explains the high recuperation of the total amount of C-terminals.

The interaction of the receptor binding domain of the $\alpha$ Ms with the LRP/ $/ \alpha_{2}-\mathrm{M}$ receptor has been extensively studied, several theories on the mechanism of removal have been presented and all of them involve one, two or four of the $\alpha$-Ms C-terminals participating in the internalization of the complexes. During the last years, the repetitive sequences of the cluster I and II of the LRP/ $\alpha_{2}-\mathrm{M}$ receptor have been identified as the domain of interaction with the receptor binding domain [23] which is exposed when the $\alpha$-Ms are complexed with proteinases. Furthermore, other ligands to the LRP/ $/ \alpha_{2}-\mathrm{M}$ receptor have been demonstrated not to compete with the binding of the $\alpha-\mathrm{M}$ complexes with the receptor, indicating an unique interaction of the complexes of the $\alpha$-Ms with the receptor [42-44].

This new purification method of the receptor binding domain will facilitate the final elucidation of the precise site of the interaction between the $\alpha-\mathrm{M}$ complexes and the $\mathrm{LRP} / \alpha_{2}-\mathrm{M}$ receptor, because the purified C-terminals of the $\alpha-$ Ms have been hydrolyzed with only two cleavage sites. Both can be used in studies with the binding site of the receptor, especially by generation of a fully functional LRP deletion mutant (minireceptor) [23]. Furthermore the purified C-terminals can be used for purification of the minireceptor and the minireceptor can be used in the purification of in vivo complexes of $\alpha$-Ms with proteinases. The $\sim 30 \mathrm{kDa}$ C-terminal as well as the $18 \mathrm{kDa}$ will contributed to size-limit the $\mathrm{C}$-terminal of the $\alpha$-Ms and may facilitate the identification of those aminoacids in the C-terminal which play a pivotal role in the interaction with $\mathrm{LRP} / \mathrm{a}_{2}-\mathrm{M}$ receptor. This will contribute to a better understanding the biological role of these two proteins in man and animals.

\section{Acknowledgments}

We thank Dr. Per-Ingvar Ohlsson for performing the sequence analysis. This investigation was supported by the Facultad de Ciencias de la Salud, the Vicerrectoría de Investigaciones of Universidad de Pamplona, Pamplona Norte de Santander-Colombia, and the Medical Faculty, University of Umeå Sweden.

\section{References}

[1] L. Sottrup-Jensen, in: F.W. Putnam (Ed.), Plasma Proteins: Structure, Function and Genetic Control, Academic Press, Orlando, FL, 1987, pp. 191-229.

[2] M.H. de Bruijn, G.H. Fey, Human complement component C3: cDNA coding sequence and derived primary structure, Proc. Natl. Acad. Sci. USA 82 (1985) 708-712.

[3] B.F. Tack, R.A. Harrison, J. Janatova, M.L. Thomas, J.W. Prahl, Evidence for presence of an internal thiolester bond in third component of human complement, Proc. Natl. Acad. Sci. USA 77 (1980) 5764 5768.

[4] A. Lundwall, I. Malmheden, G. Stålenheim, J. Sjöquist, Isolation of component $\mathrm{C} 4$ of human complement and its polypeptide chains, Eur. J. Biochem. 117 (1981) 141-146.

[5] O. Smithies, Zone electrophoresis in starch gels and its application to studies of serum proteins, Adv. Protein Chem. 14 (1959) 65-113.

[6] M.G. Damber, B. von Schoultz, F. Solheim, T. Stigbrand, K. Carlström, Prognostic value of the pregnancy zone protein during early pregnancy in spontaneous abortion, Obstet. Gynecol. 51 (1978) 677-681.

[7] P.O. Ganrot, Variation of the concentrations of some plasma proteins in normal adults, in pregnant women and in newborns, Scand. J. Clin. Lab. Invest. Suppl. 124 (1972) 83-88.

[8] P.O. Ganrot, B. Bjerre, Alpha 1-antitrypsin and alpha 2-macroglobulin concentration in serum during pregnancy, Acta Obstet. Gynaecol. Scand. 46 (1967) 126-137.

[9] M.E. Bowen, P.J. Getins, Bait region involvement in the dimer-dimer interface of human alpha 2-macroglobulin and in mediating gross conformational change. Evidence from cysteine variants that form interdimer disulfides, J. Biol. Chem. 273 (1998) 825-1831.

[10] P.M. Starkey, A.J. Barrett, Human lysosomal elastase. Catalytic and immunological properties, Biochem. J. 155 (1976) 265-271.

[11] J.B. Howell, T. Beck, B. Bates, M.J. Hunter, Interaction of alpha 2macroglobulin with trypsin, chymotrypsin, plasmin, and papain, Arch. Biochem. Biophys. 221 (1983) 261-270.

[12] B. Schmidt, L. Mitchell, F.A. Ofuso, M. Andrew, Alpha 2-macroglobulin is an important progressive inhibitor of thrombin in neonatal and infant plasma, Thromb. Haemost. 62 (1989) 1074-1077.

[13] H. Ogata, M. Kouyoumdjan, D.R. Borges, Comparison between clearance rates of plasma kallikrein and of plasma kallikrein-alphamacroglobulin complexes by the liver, Int. J. Biochem. 25 (1993) 1047-1051.

[14] L.F. Arbeláez, U. Bergmann, U. Tuuttila, V. Shanbhagh, T. Stigbrand, Interaction of matrix metalloproteinases-2 and -9 with pregnancy zone protein and alpha 2-macroglobulin, Arch. Biochem. Biophys. 347 (1997) 62-68.

[15] G.A. Chiabrando, M.A. Vides, M.C. Sanchez, Differential binding properties of human pregnancy zone protein- and alpha 2-macroglobulin-proteinase complexes to low-density lipoprotein receptor-related protein, Arch. Biochem. Biophys. 398 (2002) 73-78. 
[16] L.F. Arbeláez, T. Stigbrand, Purification of pregnancy zone protein and its receptor binding domain from human plasma, Protein Expr. Purif. 10 (1997) 301-308.

[17] O. Sand, J. Folkersen, J.G. Westergaard, L. Sottrup-Jensen, Characterization of human pregnancy zone protein. Comparison with human alpha 2-macroglobulin, J. Biol. Chem. 260 (1985) 1572315735.

[18] P.E. Jensen, L.F. Arbeláez, P.S. Vithaldas, T. Stigbrand, Preparation and characterization of a $\mathrm{C}$-terminal fragment of pregnancy zone protein corresponding to the receptor-binding peptide from human alpha 2-macroglobulin, Biochim. Biophys. Acta 1293 (1996) 254-258.

[19] P.E. Jensen, E-M. Hägglöf, L.F. Arbeláez, T. Stigbrand, V. Shanhbagh, Comparison of conformational changes of pregnancy zone protein and human alpha 2-macroglobulin, a study using hydrophobic affinity partitioning, Biochim. Biophys. Acta 1164 (1993) 152-158.

[20] L.F. Arbeláez, P.E. Jensen, T. Stigbrand, Proteinases from the fibrinolytic and coagulation system: Analyses of binding to pregnancy zone protein, a pregnancy-associated plasma proteinase inhibitor, Fibrinolysis 9 (1995) 41-47.

[21] G. Cvirn, S. Gallistl, W. Muntean, Effects of alpha 2-macroglobulin and antithrombin on thrombin generation and inhibition in cord and adult plasma, Thromb. Res. 101 (2001) 183-191.

[22] G. Cvirn, S. Gallistl, W. Muntean, Alpha 2-macroglobulin inhibits the anticoagulant action of activated protein $\mathrm{C}$ in cord and adult plasma, Haemostasis 31 (2001) 1-11.

[23] I. Mikhailenko, F.D. Battey, M. Migliorini, J.F. Ruiz, K. Argraves, M. Moayeri, D.K. Strickland, Recognition of alpha 2-macroglobulin by the low density lipoprotein receptor-related protein requires the cooperation of two ligand binding cluster regions, J. Biol. Chem. 276 (2001) 39484-39491.

[24] P.H. Jensen, S.K. Moestrup, L. Sottrup-Jensen, C.M. Petersen, J. Gliemann, Receptors for alpha 2-macroglobulin and pregnancy zone protein-proteinase complexes in the human placental syncytiotrophoblast, Placenta 9 (1988) 463-477.

[25] J. Herz, D.E. Clouthier, R.E. Hammer, LDL receptor-related protein internalizes and degrades uPA-PAI-1 complexes and is essential for embryo implantation, Cell 71 (1992) 411-421.

[26] K. Orth, E.L. Madison, M.J. Getthing, F.J. Sambrook, J. Herz, Complexes of tissue-type plasminogen activator and its serpin inhibitor plasminogen-activator inhibitor type 1 are internalized by means of the low density lipoprotein receptor-related protein/alpha 2-macroglobulin receptor, Proc. Natl. Acad. Sci. USA 89 (1992) 7422-7426.

[27] M. Gunnarsson, T. Stigbrand, P.E. Jensen, Immunochemical aberrations of alpha 2-macroglobulin purified from a patient with multiple sclerosis, Acta Neurol. Scand. 102 (2000) 406-409.

[28] S.M. Wu, S.V. Pizzo, Alpha 2-Macroglobulin from rheumatoid arthritis synovial fluid: functional analysis defines a role for oxidation in inflammation, Arch. Biochem. Biophys. 391 (2001) 119-126.

[29] Q. Liu, T.-Y. Ling, H.-S. Shieh, F.E. Johnson, S.J. Huang, Identification of the high affinity binding site in transforming growth factor- beta involved in complex formation with alpha 2-macroglobulin. Implications regarding the molecular mechanisms of complex formation between alpha 2-macroglobulin and growth factors, cytokines, and hormones, J. Biol. Chem. 276 (2001) 46212-46218.

[30] T. Chase, E. Shaw, Titration of trypsin, plasmin and thrombin with pnitrophenyl p'-guanidinobenzoate HCl, Methods Enzymol. 19 (1970) 20-27.

[31] P.E.H. Jensen, T. Stigbrand, Differences in the proteinase inhibition mechanism of human alpha 2-macroglobulin and pregnancy zone protein, Eur. J. Biochem. 210 (1992) 1071-1077.

[32] L. Sottrup-Jensen, J. Folkersen, T. Kristensen, B.F. Tack, Partial primary structure of human pregnancy zone protein: extensive sequence homology with human alpha 2-macroglobulin, Proc. Natl. Acad. Sci. USA 81 (1984) 7353-7357.

[33] P.K. Hall, R.C. Roberts, Physical and chemical properties of human plasma alpha 2-macroglobulin, Biochem. J. 173 (1978) 27-38.

[34] L. Sottrup-Jensen, J. Gliemann, F. van Leuven, Domain structure of human alpha 2-macroglobulin. Characterization of a receptor-binding domain obtained by digestion with papain, FEBS Lett. 205 (1986) 20-24.

[35] E. Engvall, Enzyme Immunoassay Elisa and Emit, Methods Enzymol. 70 (1980) 419-439.

[36] U.K. Laemmli, Cleavage of structural proteins during the assembly of the head of bacteriophage T4, Nature 227 (1970) 680-685.

[37] J.B. Howard, M. Vermeulen, R.P. Swenson, The temperature-sensitive bond in human alpha 2-macroglobulin is the alkylamine-reactive site, J. Biol. Chem. 255 (1980) 3820-3823.

[38] N.K. Thomsen, L. Sottrup-Jensen, Alpha-macroglobulin domain structure studied by specific limited proteolysis, Arch. Biochem. Biophys. 300 (1993) 327-334.

[39] A. Bodi, K. Gyula, I. Istvan, L. Graf, Structural determinants of the half-life and cleavage site preference in the autolytic inactivation of Chymotrypsin, Eur. J. Biochem. 268 (2001) 6238-6246.

[40] W.K. Bauman, S.A. Bizzozero, H. Dutler, Specificity of alpha-chymotrypsin. Dipeptide Substrates, FEBS Lett. 8 (1970) 257-260.

[41] I.V. Berezin, K. Martinek, Specificity of alpha-chymotryspin, FEBS Lett. 8 (1970) 261-262.

[42] M.M. Hussain, F.R. Maxfield, J. Mas-Oliva, I. Tabas, Z-S. Ji, T.L. Innerarity, R.W. Mahley, Clearance of chylomicron remnants by the low density lipoprotein receptor related protein/alpha 2-macroglobulin receptor, J. Biol. Chem. 266 (1991) 13936-13940.

[43] G. Bu, S. Williams, D.K. Strickland, A.I. Skwartz, Low density lipoprotein receptor-related protein/alpha 2-macroglobulin receptor is an hepatic receptor for tissue type plasminogen activator, Proc. Natl. Acad. Sci. USA 89 (1992) 7427-7431.

[44] I.R. Horn, S.K. Moestrup, B.M. van den Berg, H. Pannekoek, M.S Nielsen, A.J. van Zonneveld, Analysis of the binding of pro-urokinase and urokinase-plasminogen activator inhibitor-1 complex to the low density lipoprotein receptor-related protein using a Fab fragment selected from a phage-displayed Fab library, J. Biol. Chem. 270 (1995) 11770-11775. 